\title{
KEBUTUHAN BIOLOGIS NARAPIDANA SEUMUR HIDUP DI LEMBAGA PEMASYARAKATAN KELAS II B CIANJUR
}

\author{
${ }^{1}$ Tiyas Argian Pramadhani, ${ }^{2}$ MitroSubroto \\ ${ }^{12}$ Politeknik Imu Pemasyarakatan \\ ${ }^{I}$ E-Mail: tiyasargian1712@gmail.com \\ ${ }^{2}$ E-Mail: subrotomitro007@gmail.com
}

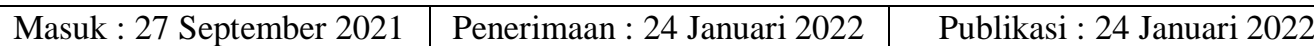

\section{ABSTRAK}

Tujuan penelitian ini yaitu untuk mengetahui bagaimana perlakuan bagi narapidana seumur hidup serta efektifitas pemberlakuan kebijakan perlakuan tersebut ditinjau dari sudut pandang kebutuhan biologis bagi narapidana seumur hidup. Penelitian ini bersifat deskriptif dengan menggunakan pendekatan kualitatif. Pelaksanaan pengumpulan data dalam penelitian ini dengan pengamatan dan penggalian data benupa wawancara yang dilakukan dengan narapidana terkait. Pelaksanaan perlakuan terhadap narapidana seumur hidup ini merupakan salah satu cara demi tercapainya efektivitas pelaksanaan pembinaan yang diterima. Berdasarkan penelitian yang dilakukan, diperoleh hasil bahwa efektivitas perlakuan dalam upaya pembinaan narapidana di Lapas Kelas II B Cianjur sudah dilaksanakan namun pelaksanaan perlakuan tersebut masih ada beberapa kekurangan dikarenakan adanya kendala-kendala yang menghambat pelaksanaan kebijakan perlakuan terhadap narapidana seumur hidup dari sisi sosialisasi kebijakan, dan juga sarana dan prasarana yang ada. Apabila hambatan-hambatan tersebut tidak dapat diatasi, maka akan menimbulkan berbagai penyimpangan seksual seperti disorientasi seksual, LGBT, dan menggunakan benda yang tidak seharusnya digunakan sebagai pemuas kebutuhan biologis.

Kata Kunci $\quad$ : Biologis; Kebijakan; Narapidana; Pembinaan;Pidana.

\section{ABSTRACT}

The purpose of this study is to find out how the treatment for lifelong prisoners and the effectiveness of the implementation of the treatment policy is viewed from the point of view of biological needs for lifelong prisoners. This research is descriptive using a qualitative approach. The implementation of data collection in this study was carried out by obsenving and extracting data in the form of interviews with related prisoners. The implementation of treatment for lifelong prisoners is one way to achieve the effectiveness of the implementation of the guidance received. Based on the research conducted, it was found that the effectiveness of treatment in the effort to foster prisoners at the Class II B Cianjur Prison has been implemented but the implementation of the treatment still has some shortcomings due to obstacles that hinder the implementation of the policy on treatment of lifelong prisoners in terms of policy socialization, and as well as existing facilities and infrastructure. If these obstacles cannot be overcome, it will lead to various sexual deviations such as sexual disorientation, LGBT, and using objects that should not be used to satisfy biological needs.

Keywords $\quad$ : Biological; Policy; Prisoners; Coaching; Criminal. 


\section{A. PENDAHULUAN}

Pidana penjara merupakan salah satu dari pidana pokok yang paling sering dijatuhkan oleh majelis hakim dalam putusannya untuk menyelesaikan dan mengadili setiap perkara perkara pidana. Pidana penjara adalah suatu pidana berupa pembatasan kebebasan bergerak dari seorang terpidana atau dengan kata lain berupa perampasan kemerdekaan seorang terpidana dalam waktu tertentu yang ditempatkan di Lembaga Pemasyarakatan (dahulu disebut penjara) (Maulani, 2014).

Pada perkembangan zaman saat ini, pelaksanaan pidana yang ada dan dilakukan semakin menjadi bervariasi dari mulai undang-undang mengenai perlindungan hak asasi manusia hingga Undang-Undang ITE. Hal ini membuat semakin banyaknya pelanggar yang melakukan tindakan pidana yang ada saat ini dan membuat suatu permasalahan baru hingga membuat semakin banyak dan penuhnya narapidana penghuni Lapas yang ada di Indonesia.

Satu dari dua jenis pidana penjara di indonesia yang diatur dalam Pasal 12 KUHP adalah Pidana penjara seumur hidup. Selengkapnya, Pasal 12 ayat (1) KUHP berbunyi, pidana penjara ialah seumur hidup atau selama waktu tertentu. Dalam Pasal 12 ayat (4) KUHP dinyatakan, pidana penjara selama waktu tertentu sekali-kali tidak boleh melebihi 20 (dua puluh) tahun.

Dengan penjelasan diatas mengenai pidana seumur hidup dapat disimpulkan bahwa yang di maksud dari pidana penjara seumur hidup yaitu penjara selama seseorang terpidana masih hidup hingga ia meninggal dunia. Kebijakan tersebut juga sekaligus menolak atau mematahkan pendapat bahwa hukuman pidana penjara yang dijatuhkan kepada terpidana adalah selama usia terpidana pada saat dijatuhkan vonis.

Maka dari itu dengan adanya pidana tersebut semakin menjadi berat bagi terpidana dengan tindak pidana yang dilakukan, semakin banyak dan semakin lama vonis dijatuhkan bagi terpidana tersebut maka semakin banyak dan semakin lama juga hak-hak yang tidak bisa didapat oleh terpidana tersebut. Seperti hal nya sudah pasti hilang kebebasan bergerak bagi terpidana karena harus menjalani kehidupan di dalam lapas selama hidupnya dan juga hak lain yang tidak dapat di dapatkan. 
Pidana penjara seumur hidup seperti halnya dengan pidana mati, padadasarnya merupakan jenis pidana absolut. Dilihat dari sudut penjatuhan pidana dan juga dari sudut terpidana, pidana seumur hidup itu bersifat pasti (definite sentence) karena si terpidana dikenakan jangka waktu yang pasti ( $a$ definite period of time), yaitu menjalani pidana sepanjang hidup seorang di dunia ini (Maulani, 2014). Perilaku narapidana di dalam lembaga pemasyarakatan sangat dipengaruhi oleh perilaku mereka ketika belum masuk ke dalam penjara. Andrews dan Bonta mengungkapkan tentang criminogenic needs atau faktor risiko yang ada pada diri perilaku kriminal dan berkorelasi dengan perilaku kriminal (Haryono, 2017).

Hak-hak narapidana masih sama seperti orang pada umumnya walaupun mereka sudah dijatuhkan hukuman dan juga menjalani masa hukuman tersebut tetapi hak-hak bagi mereka masih melekat sebagai seorang manusia (Utami, 2017). Hak dasar harus dipenuhi dengan baik seperti hak hidup, hak untuk beribadah sesuai dengan agama dan kepercayaan masing-masing, hak untuk mendapatkan perawatan kesehatan, hak untuk bersosialisasi dengan masyarakat dan juga hak-hak lain yang dimana negara harus memberikan itu walaupun narapidana tersebut berada di dalam penjara selama menjalani hukuman yang ada. Selain dari hak tersebut ada juga hak lain yang harus dipenuhi sebagai seorang manusia. Hak biologis bagi seluruh manusia yang ada di muka bumi harus juga dipenuhi dan didapatkan. Berkaitan dengan adanya pidana seumur hidup yang dijalani setiap orang yang mendapatkan vonis hukuman seumur hidup bahwasanya hak biologis menjadi salah satu permasalahan yang ada. Lama-nya narapidana di penjara di dalam lapas membuat mereka tidak bisa bertemu dengan keluarga dan juga apabila sebagai seorang narapidana yang sudah mempunyai istri maka dia mempunyai kebutuhan biologis untuk menyalurkan nya kepada istri nya sebagai seorang manusia dan suami yang membutuhkan hak tersebut.

Maslow membagi kebutuhan dasar manusia menjadi 5 tingkatan, dimana tingkat yang paling dasar adalah Physiological need yaitu Kebutuhan fisiologis, lalu kebutuhan yang lebih tinggi Safety and Security needs yaitu Kebutuhan keselamatan dan keamanan (setelah terpenuhi maka kebutuhan manusia meningkat ke Love and Belonging needs yaitu 
Kebutuhan cinta dan rasa memiliki, kebutuhan yang lebih tinggi adalah Esteem need yaitu Kebutuhan rasa berharga dan harga diri, dan kebutuhan yang paling tinggi, yang menurut Maslow hanya bisa dicapai setelah semua kebutuhan terpenuhi adalah Self Actualization yaitu Kebutuhan aktualisasi diri (Citrawan, 2013).

Pelaksanaan pemberian hak bagi narapidana seperti sebagaimana yang dijelaskan diatas tergantung dengan perlakuan dalam konteks pembinaan bagi narapidana yang ada di dalam lapas di Indonesia, maka dari itu kebijakan perlakuan terhadap narapidana dalam pemenuhan kebutuhan hakhak dasar maupun hak biologis narapidana yang ada di lapas khususnya narapidana seumur hidup harus dilaksanakan dan di buat dengan baik dan benar.

Namun, pemenuhan kebutuhan biologis pada Lapas Kelas II B Cianjur belum terlaksana. Hal ini terjadi akibat beberapa pertimbangan yang harus dilakukan sebelum menerapkan kebijakan tersebut. Mulai dari peraturan, pengadaan sarana dan prasarana, serta kondisi sosial yang ada di dalam lapas. Berbagai pertimbangan tersebut dilakukan agar keamanan dan ketertiban lapas tetap terjaga. Apabila berbagai pertimbangan tersebut dilalaikan, maka kemungkinan yang dapat terjadi adalah adanya kecemburuan sosial di lingkungan lapas sehingga dapat berkibat pada kerusuhan dan terganggunya ketertiban di lapas.

\section{B. METODE}

Penelitian yang akan digunakan dalam pelaksanaan penelitian ini dengan menggunakan metode penelitian lapangan (Field Research), yaitu mencari data dengan melakukan interview mengenai fenomena atau permasalahan yang terjadi di dalam Lapas secara langsung kepada narapidana yang mendapatkan hukuman seumur hidup dan juga masyarakat yang diperoleh berdasarkan data yang relevan.

Sebagaimana dijelaskan di atas bahwasanya pelaksanaan penelitian mengenai hak biologi bagi warga binaan pemasyarakatan dengan hukuman seumur hidup maka sumber data yang diperlukan adalah Data Primer yang merupakan keterangan fakta yang diperoleh langsung dari hasil wawancara 
dengan narapidana seumur hidup di Lapas Kelas II B Cianjur, mengenai perlakuan dan pemberian hak yang sudah diberikan kepada narapidana tersebut, dan khususnya mengenai pemenuhan kebutuhan biologis narapidana seumur hidup. Kemudian Data Sekunder berupa Undang-Undang Pemasyarakatan, kebijakan undang-undang lain yang berkaitan dengan permasalahan, dan literature-literatur yang berkaitan dengan permasalahan dalam rangka menunjang kelengkapan informasi yang ada.

Dalam rangka mendapatkan data dalam penelitian ini, dibutuhkan beberapa teknik pengumpulan data untuk mendapatkan informasi data primer dan data sekunder yang hasilnya nanti akan dianalisis. Teknik pengumpulan data yang digunakan dalam penelitian ini yaitu wawancara yang merupakan suatu percakapan dengan tujuan. Tujuan dari wawancara sendiri adalah untuk memperoleh konstruksi yang terjadi saat ini mengenai permasalahan yang ada dan terjadi di dalam Lapas bagi setiap narapidana dengan hukuman seumur hidup. Pelaksanaan wawancara dalam rangka mendalami dan menjadi bahan tambahan data. Penelitian ini merupakan penelitian kualitatif yaitu jenis penelitian yang tidak didapatkan melalui prosedur hitungan atau statistik. Data-data serta informasi yang diperoleh berdasarkan sampel-sampel data yang dikumpulkan melalui instrumen yang mendukung adanya penelitian. Yang mana pengambilan sampel data berdasarkan teori-teori dan penelitian yang sudah ada sebelumnya.

\section{HASIL ATAU PEMBAHASAN}

\section{Pelaksanaan Hak Asasi Manusia dalam Pemenuhan Kebutuhan Biologis}

Pada kesempatan ini, pertama-tama penulis akan menjelaskan mengenai pelaksanaan HAM secara legal normatif kebutuhan biologis sebagai dari bagian hak asasi manusia bagi setiap orang dan tidak terlepas bagi narapidana seumur hidup yang harus diberikan. Pada pembahasan ini, agar dapat membangun logika terhadap kasus ini, penulis membagi hak-hak terkait menjadi tiga bagian yaitu hak atas perlakuan manusiawi, hak atas masalah pribadi dan keluarga, dan yang 
terakhir hak atas kesehatan dan kehidupan yang layak. Sementara itu pada pelaksanaan pencarian data primer yang didapatkan pada saat melakukan wawancara terhadap narapidana seumur hidup akan disisipkan ke dalam bagianbagian tersebut dan selanjutnya akan digunakan sebagai analisis mekanisme kebijakan pemenuhan kebutuhan biologis narapidana seumur hidup.Tujuan pembinaan narapidana dalam Sistem Pemasyarakatan menurut Undang Undang Nomor 12 tahun 1995 (UU 12/1995) Pasal 2 adalah: Membentuk Warga Binaan Pemasyarakatan agar menjadi warga binaan seutuhnya, menyadari kesalahan, memperbaiki diri dan tidak lagi mengulangi tindak pidana sehingga dapat diterima lagi oleh lingkungan masyarakat dapat aktif berperan dalam pembangunan dan dapat hidup sebagai warga yang baik dan bertanggung jawab (Rachmayanthy et al., 2020).

\section{Kebutuhan Biologis dalam Hak Perlakuan Manusiawi}

Secara normatif, Kovenan Internasional Hak-Hak Sipil dan Politik mengatur bahwa setiap orang yang dirampas kebebasannya, termasuk para narapidana di lembaga pemasyarakatan, wajib diperlakukan secara manusiawi dan dengan menghormati martabat yang melekat pada diri manusia. Lebih lanjut pada General Comment No. 21, Komite HAM untuk Kovenan menafsirkan hak tersebut dengan penjelasan sebagai berikut:

"Article 10, paragraph 1, imposes on States parties a positive obligation towards persons Seksualitas dalam Penjara... | Harison Citrawan |35who are particularly vulnerable because of their status as persons deprived of liberty, and complements for them the ban on torture or other cruel, inhuman or degrading treatment or punishment contained in article 7 of the Covenant. Thus, not only may persons deprived of their liberty not be subjected to treatment that is contrary to article 7, includ-ing medical or scientific experimentation, but neither may they be subjected to any hardship or constraint other than that resulting from the deprivation of liberty; respect for the dignity of such persons must be guaranteed under the same conditions as for that of free persons. Persons deprived of their liberty enjoy all the rights set forth in the Covenant, subject to the restrictions that are unavoidable in a closed environment" 
Makna dari penafsiran Komite HAM tersebut adalah pada prinsipnya, pengekangan terhadap kebebasan (deprivation of liberty) hanya boleh ditimpakan pada kebebasan bergerak seseorang. Secara manusiawi dan dalam konteks perlakuan maka dapat dilihat bahwasanya perlakuan kepada narapidana walaupun dilaksanakan di dalam lapas tetapi harus dilaksanakan seperti warga masyarakat biasa dan harus dijunjung tinggi haknya. Maka dari itu kebijakan dalam perlakuan terhadap narapidana harus dibuat sedemikian rupa agar dapat menjaga pelaksanaan pemberian hak perlakuan bagi narapidana tersebut, apalagi untuk pelaksanaan perlakuan narapidana seumur hidup semakin lama dia di dalam lapas maka akan semakin banyak juga pelaksanaan perlakuan yang harus dilakukan sesuai dengan hak asasi manusia dalam pelaksanaan perlakuan tersebut.

\section{Kebutuhan Biologis dalam Hak atas Masalah Pribadi dan Keluarga}

Dalam hal perspektif hak asasi manusia, khususnya dalam hak sipil, keluarga merupakan kesatuan kelompok masyarakat yang terbentuk secara alamiah dan mendasar yang akhirnya berhak untuk dilindungi oleh masyarakat luas dan negara. Pada hal ini, negara pada dasarnya wajib melindungi seluruh unsur masyarakat yang ada didalamnya salah satunya dalam unsur terkecil adalah keluarga. Perlindungan tersebut berbentuk perlindungan individu yang nantinya akan membentuk unsur-unsur ikatan lainnya dan terutama peluang untuk berproduksi (possibility to procreats).

Dari dimensi hak atas masalah pribadi (privacy), sebagaimana termaktub dalam Pasal 17 Kovenan,7 aturan HAM yang ada belum mengatur secara spesifik tentang ruang lingkup masalah pribadi vis-a-vis kebutuhan biologis. Namun, dari praktik perlindungan HAM di Pengadilan Hak Asasi Manusia Eropa (European Court of Human Rights), kehidupan pribadi (private life) merupakan konsep yang mencakup integritas fisik dan moral seseorang, termasuk kehidupan seksualnya. Lebih lanjut, Ursula Kilkelly menjelaskan bahwa:

"A person's sexual life is part of his private life, of which it constitutes an important aspect. Private life thus guarantees a sphere within which a person can establish relations of different kinds, including sexual ones and thus the choice of affirming and assuming one's sexual identity comes within the protec-tion of Article 8." 
Dari alur logika yang ada di atas pada dasarnya prinsipnya yaitu dapat memberikan kkia pada gambaran bahwa kebutuhan biologis yang merupakan unsur hak asasi manusia merupakan hak yang penting dalam perwujudan hak atas masalah pribadi dan juga keluarga. Pada narapidana seumur hidup apalagi pada hakikatnya bahwasanya dia merupakan seseorang dalam derajatnya bisa jadi seorang ayah dan suami bagi keluarganya, maka dari itu hak biologis tersebut harus melindungi dan memenuhi kebutuhan tersebut secara proporsional agar pada pelaksanaannya walaupun narapidana tersebut berada di dalam lapas tetapi masih menjadi seorang masyarakat yang berada di bawah negara.

\section{Kebutuhan Biologis dalam Hak Atas Kesehatan dan Hidup Yang Layak}

Pelaksanaan pidana penjara yang dilakukan di indonesia semakin banyak membuat lapas yang ada di indonesia melampaui batas kapasitas maksimum jumlah isi dari Lapas tersebut, hal ini membuat beberapa permasalahan terjadi dari pelaksanaan pembinaan hingga masalah perawatan baik bagi tahanan maupun narapidana. Dalam pelaksanaan perawatan kesehatan yang diterima oleh warga binaan dilaksanakan dengan prosedur yang ada dan melihat kondisi lapangan di Unit Pelaksanaan Teknis (UPT) tersebut. Semakin banyaknya narapidana yang ada di lapas semakin membuat kesehatan narapidana menjadi kurang begitu baik, berdesakan di dalam kamar hingga lingkungan kamar yang kurang begitu baik dalam sirkulasi udara akibat penuhnya kamar tersebut. Makna hidup dapat ditemukan dalam kehidupan itu sendiri, betapapun buruknya kehidupan tersebut. Makna hidup tidak saja dapat ditemukan dalam keadaan-keadaan yang menyenangkan, tetapi juga dapat ditemukan dalam penderitaan sekalipun, selama kita mampu melihat hikmah-hikmahnya (Lubis \& Maslihah, 2012).

Masalah kesehatan terjadi selain dari kurangnya sarana dan prasarana hingga penuhnya isi lapas di indonesia, bisa juga diakibatkan oleh kehidupan narapidana tersebut. Semakin lama mereka di dalam lapas maka semakin lama juga iya tidak dapat menyalurkan kebutuhan biologis dari kehidupannya sendiri. 
Dari hal ini sering kali narapidana tersebut membuat suatu jalan pintas yaitu sering terjadinya narapidana yang gay dikarenakan untuk melepaskan hasrat keinginan birahi dalam konteks kebutuhan biologis ini.

Terjadinya penyimpangan ini membuat suatu permasalahan lain yang membuat kesehatan narapidana dapat terganggu dengan adanya penyakit yang dapat menular seperti HIV/AIDS yang membuat terjadinya penyimpangan tersebut dapat berpengaruh terhadap kebutuhan kesehatan bagi narapidana apalagi narapidana seumur hidup, maka dari itu dilihat dari adanya permasalahan kesehatan dikarenakan penyakit menular yang dapat timbul di dalam lapas. Negara wajib memberikan pelayanan dan wajib melindungi juga memberikan pemenuhan kebutuhan secara baik dan benar.

Hasil atau pembahasan merupakan jawaban dari permasalahan yang digambarkan pada pendahuluan, termasuk dengan hasil analisis statistiknya dipaparkan secara terperinci dalam bagian ini Ilustrasi, jika diperlukan dapat disajikan dalam bentuk tabel dan/atau gambar. Tabel dan gambar harus sederhana, informatif, mudah dipahami dan mandiri, dalam arti tabel atau gambar dimaksud harus bisa menjelaskan kepada pembaca sehingga pembaca memahaminya.

\section{Pemenuhan atas Hak Biologis}

Pada bagian ini, penulis akan mendasarkan analisis berdasarkan data temuan yang diperoleh pada saat pencarian sumber daya di lokasi Unit Pelaksana Teknis (UPT) Lembaga Pemasyarakatan Kelas IIB Cianjur terhadap salah satu narapidana hukuman seumur hidup. Dari data yang didapatkan pada pelaksanaan pencarian data, setidaknya ada tiga aspek yang akan menjadi landasan dalam melaksanakan analisis mengenai bagaimana pemenuhan kebutuhan hak biologis bagi narapidana hukuman seumur hidup.

Pertama, unsur kepentingan narapidana. Pelaksanaan wawancara dilakukan secara mendalam terhadap 4 narapidana laki-laki dan 1 narapidana perempuan yang mendapatkan hukuman vonis seumur hidup di Lapas Kelas IIB Cianjur yang telah menikah dan berkeluarga juga ada yang sudah mempunyai anak di luar sana, pada pelaksanaan wawancara yang dilakukan dengan memusatkan pada aspek 
kebutuhan narapidana dari kelima narasumber yang sudah di wawancara didapat titik temu dalam permasalahan ini bahwasanya pada dasarnya mereka sebagai manusia memang mengakui terdapat kebutuhan akan penyaluran hasrat atau keinginan biologis pada saat mereka sedang melaksanakan masa hukuman di dalam Lapas. Dari keempat narapidana yang sudah di wawancara, mereka menyadari bahwasanya pada saat sekarang ketika mereka di dalam Lapas mereka harus menahan kebutuhan biologis tersebut dikarenakan dengan kondisi isolatif mereka. Kebutuhan dasar manusia, dalam perspektif hak asasi manusia, merupakan sesuatu yang mutlak diberikan kepada setiap manusia tanpa pengecualian. Akan tetapi, pada tataran praktik, pranata peraturan negara dan tata nilai yang hidup di masyarakat tidak selalu sejalan dengan ide dari perlindungan hak asasi manusia. Menurut WHO, dalam implementasinya perlu ada: pemberian hak yang sama bagi napi wanita dan napi pria, ada prosedur yang tidak merendahkan napi di mata staf, dan ada tersedia kondom.

Dari beberapa narapidana tersebut kita harus melihat hal penting yang harus kita catat bahwasanya untuk menyikapi kebutuhan biologis yang mereka punya dan mungkin belum bisa disalurkan dikarenakan pada dasarnya mereka sedang melaksanakan masa hukuman : (i) melaksanakan kegiatan fisik di dalam Lembaga Pemasyarakatan seperti berolahraga, kegiatan kerja, ataupun melaksanakan kegiatan sebagai tahanan pendamping, (ii) melaksanakan aktivitas kejiwaan dan mendekatkan diri kepada yang maha kuasa seperti beribadah, siraman rohani, pelaksanaan konseling dengan pihak ketiga, dan ceramah tematik yang dilaksanakan oleh kerja sama antara pihak Lembaga Pemasyarakatan dan juga pemerintah ataupun organisasi lain, (iii) melakukan masturbasi.

Kedua, unsur keamanan. Berdasarkan informasi yang diperoleh pada saat mewawancarai salah satu petugas di Lembaga Pemasyarakatan Kelas IIB Cianjur, terdapat beberapa perhatian yang diambil oleh pihak Lembaga Pemasyarakatan terkait dengan pelaksanaan pemenuhan kebutuhan biologis (i) dengan ketidaktersediaan infrastruktur dan sumber daya manusia. Mengenai hal ini dengan selalu bertambahnya pelanggar hukum di indonesia yang menyebabkan permasalahan baru di dalam Lapas salah satunya overcrowding sampai saat ini 
apabila melihat di lapangan para petugas masih belum siap apabila ada peraturan atau kebijakan terhadap diperbolehkannya pemenuhan kebutuhan biologis bagi narapidana umum maupun hukuman seumur hidup, sumber daya manusia yang ada di dalam lapas juga masih tergolong kurang karena apabila dibandingkan dengan jumlah narapidana yang ada di dalam masih lebih banyak narapidana di dalam.; (ii) kerumitan mekanisme pelaksanaan pemberian pemenuhan kebutuhan biologis. Pada poin ini, petugas masih terbilang kebingungan dengan bagaimana mekanisme yang akan diberikan apabila dilaksanakannya pelaksanaan pemenuhan kebutuhan biologis bagi narapidana. Sebelumnya sudah ada beberapa mekanisme yang dicoba seperti pembuatan bilik asmara (conjugal room) tetapi disana masih ada beberapa kekurangan seperti adanya kecemburuan antar narapidana yang ada di dalam. Maka dari itu dengan melihat beberapa aspek diatas, terhadap keamanan lapas sangat diperhitungkan untuk mekanisme pelaksanaan pemberian kebutuhan bagi narapidana hukuman seumur hidup.

Ketiga, aspek atau unsur kehidupan masyarakat sebagai aspek yang penting dalam menganalisa fenomena yang terjadi di dalam Lapas. Kita ketahui bahwasanya masyarakat sebagai unsur dalam pembentukan kehidupan di luar lapas menjadi salah satu gardah dalam pembentukan karakter seorang anggota masyarakat setelah adanya sebuah keluarga. Mengingat dalam pelaksanaan pemasyarakatan yang digagas dalam pelaksanaan sistem kepenjaraan di indonesia yang diharapkan menjadi wadah rehabilitatif agar seorang narapidana kembali ke dalam masyarakat dan melakukan reintegrasi sosial bersama masyarakat kembali. Dalam hal ini masyarakat menjadi penting dan signifikan dalam pertimbangan terkait pelaksanaan pola pembinaan dan pemenuhan hak-hak narapidana selama mereka masih di dalam lapas.

Apabila melihat dari segi masyarakat yang bisa kita ambil dari sisi agama sebagai pondasi terjadinya kehidupan masyarakat mayoritas di indonesia, secara agama seseorang yang melakukan kesalahan atau pelanggaran memang seharusnya mafhum akan kondisinya tersebut sebagai seorang narapidana yang sedang melaksanakan masa pidana dan harus dipenjara baik kejiwaannya dan juga fisiknya. Oleh sebab itu kebutuhan biologis bagi para pelanggar hukum yang menjadi tuntutan narapidana yang ada di dalam lapas saat ini baik narapidana 
yang mendapatkan vonis biasa maupun seumur hidup harus dikesampingkan demi efek jera (deterrent effect).

Dari hal diatas mengenai pelaksanaan efek jera dilihat dari segi agama bahwasanya apabila nanti pelaksanaan pemberian kebutuhan biologis yang ada bagi narapidana tersebut diberikan maka ditakutkan akan terjadi penyalahgunaan dan penyimpangan kebijakan dalam mekanisme pelaksanaan pemberian tersebut, hal ini dapat menyalahi aturan agama yang dimana agama melarang cara-cara seperti itu.

Kebutuhan biologis memang menjadi salah satu hak yang dibutuhkan oleh seluruh masyarakat tetapi dalam pelaksanaannya tidak semuanya bisa dilaksanakan sesuai dengan keinginan dan hak yang dimiliki oleh mereka, sebagai seorang pelanggar hukum tentu pasti ada beberapa aspek yang hilang dari mulai kebebasan bergerak dan lain sebagainya.

Dari data wawancara terhadap narapidana yang sudah dilakukan, mereka berpendapat bahwa kebutuhan itu memang ada dan mereka menginginkannya tetapi dengan keterbatasan tersebut tidak bisa semua yang diinginkan dijalankan dengan baik dan bisa didapatkan. Salah satu warga binaan juga menyebutkan dia memang sangat rindu sekali akan keluarga apalagi dengan istrinya, hasrat yang selalu ada selalu membayangi dirinya tetapi dengan adanya dia di dalam penjara membuat semakin susah.

Dalami pelaksanaani pembinaani dani perawatani dii dalami lembagai pemasyarakatan, seluruh Unit Pelaksana Teknis melaksanakannya sesuai dengan Nomor M.02-PK.04.10 Tahun 1990 Tentang Pola Pembinaan Narapidana/Tahanan yang dilaksanakan. Dari data data diatas dapat kita ketahui bahwasanya kebutuhan biologis bagi narapidana seumur hidup memang sangat dibutuhkan dan sangat diinginkan oleh narapidana tersebut tetapi dalam pelaksanaannya para petugas masih harus tetap melaksanakan kebijakan pembinaan, pelayanan dan perawatan sesuai dengan prosedur yang ada. Namun demikian, semakin berkembangnya ilmu pengetahuan akan semakin berkembang juga pemikiran, tanpa terkecuali dengan pemikiran terhadap kasus ini. Pada dasarnya semakin lama manusia akan semakin tercipta rasa kemanusiaannya. 
Melihat narapidana seumur hidup yang hanya diam di dalam lapas dan tidak bisa bertemu dengan keluarga menjadi semakin membuat rasa kemanusiaan tertanam walaupun mereka sebagai seorang pelanggar hukum tetapi mereka masih sebagai manusia dan anggota masyarakatnya. Panduan lembaga pemasyarakataan melalui rehabilitasi agar mampu membentuk sesuai dengan kepribadian dan mentalitas narapidana/warga binaan yang dianggap tidak memadai di mata komunitas untuk berubah menjadi rata-rata arah dan mengikuti norma yang telah berlaku dan hukum. Dalam pelaksanaan ini bimbingan membutuhkan kerjasama dari komponen yang mendukung keberhasilan proses pembinaan narapidana, yaitu petugas lapas, rehabilitasi lembaga, narapidana/penduduk binaan, dan Komunitas. Ini karena empat dari mereka saling berkelanjutan dengan satu sama lain (Mulyana et al., 2021).

Maka dari itu, jajaran pemasyarakatan melaksanakan program pembinaan yang semakin maju dan terus diperbaharui sesuai dengan kemajuan zaman dan ilmu pengetahuan. Dengan adanya rasa manusiawi dari mulai awal adanya penjara dengan sistem Penjeraan, pemberian rasa sakit terhadap pelanggar hukum, saat itu di indonesia pelaksanaan pembinaan atau sistem yang ada di dalam penjara menggunakan sistem pemasyarakatan dimana yang diharapkan nantinya para narapidana kembali berintegrasi dengan masyarakat walaupun sudah melakukan pelanggaran hukum dan dapat memulihkan hubungan hidup, kehidupan dan penghidupan.

Di dalam sudut pandang mengenai hak biologis bagi narapidana seumur hidup jajaran pemasyarakatan menyikapi dengan sangat serius dan akhirnya membuat suatu program yang bisa didapatkan dan dilaksanakan oleh narapidana yaitu salah satunya dengan adanya pemberian Cuti Mengunjungi Keluarga (CMK). Dengan adanya hal ini diharapkan akan bisa memenuhi pemberian hak kebutuhan biologis bagi narapidana tersebut. Maka dari itu dengan adanya kebijakan ini jajaran pemasyarakatan sudah begitu melaksanakan program yang di dasari dengan kepentingan hak bagi narapidana walaupun mereka di dalam lapas.

Pada Lembaga Pemasyarakatan Kelas II B Cianjur masih belum bisa menerapkan sepenuhnya mengenai pemenuhan hak-hak biologis bagi narapidana. Hal ini akibat dari overcrowded yang terjadi di lapas, sehingga tidak semua hak- 
hak yang dimiliki oleh narapidana dapat terpenuhi dengan baik. Terutama kebutuhan biologis narapidana. Perbandingan antara kapasitas yang dimiliki oleh lapas dengan jumlah narapidana yang berlebih, menyebabkan penggunaan fasilitas yang tidak semestinya demi dapat menampung jumlah narapidana.

Hingga kemudian muncul pandangan bahwa, pemenuhan kebutuhan biologis bagi narapidana dapat dilakukna dengan adanya bilik asmara. Hal itu dirasa cukup membantu dalam pemenuhan hak biologis narapidana, tanpa harus narapidana itu keluar dari lingkungn lapas. Ini juga dapat memperkecil resiko terjadinya pelarian narapidana. Namun, upaya pemenuhan hak biologis narapidana tersebut memiliki resiko yang cukup tinggi. Diantaranya terbatasnya sarana dan prasarana untuk pembuatan bilik asmara, bilik asmara hanya dapat digunakan oleh narapidana yang telah menikah sehingga dapat menimbulkan kecemburuan sosial dintara narapidana lainnya kemudian dapat timbul upaya penyogokan dan resiko munculnya prostitusi di dalam lapas akan semakin besar, tidak semua pasangan dari narapidana yang bersangkutan mau untuk melakukan hubungan suami istri di lingkungan lapas, dan pihak lapas harus ekstra memastikan bahwa dengan adanya bilik asmara tidak akan menimbulkan penyakit menular seksual.

Pemerintah dan Lapas Kelas II B Cianjur telah melakukan upaya agar dapat memenuhi kebutuhan biologis narapidana. Dintaranya pemberian Cuti Mengunjungi Keluarga (CMK) yangmana dapat digunakan oleh narapidana yang bersangkutan untuk memenuhi kebutuhan biologisnya. Hal ini juga telah berlaku di beberapa negara seperti Denmark, Belanda, dan Swedia. Namun terdapat perbedaan pda penerapannya, yangmana negara-negara tersebut memberikan izin bagi narapidana untuk mendapat kunjungan dari suami/istri dalam waktu tiga jam. Waktu tersebut dihabiskan oleh narapidana dan pasangannya di dalam sebuah ruangan yang difasilitasi tempat tidur, kamar mandi, dan fasilitas lain. Selain itu, narapidana yang berada di Pakistan diberikan izin untuk dikunjungi secara pribadi oleh pasangan mereka dua kali dalam satu bulan selama satu malam.

Penerapan Cuti Mengunjungi Keluarga (CMK) yang telah diterapkan di Indonesia dirasa cukup memenuhi kebutuhan biologis narapidana. Pasalnya izin ini dibeikan paling singkat tiga bulan sekali dan diberikan maksimal 2x24 jam 
setiap kali perizinannya yang kemudian akan dijemput kembali. Namun penerapan ini hanya berlaku bagi narapidana tindak pidana umum yang mendapat beberapa tahun kurungan penjra, sehingga dapat dirasa kurang adil bagi narapidana yang menjalani hukuman seumur hidup. Yangmana sejatinya semua manusia memiliki hak yang sama.

\section{PENUTUP}

Pidana penjara memang merupakan jalan terakhir bagi para masyarakat yang melakukan tindakan pelanggaran yang menyebabkan dia harus mendekam di dalam penjara selama vonis yang ia dapatkan. Semakin lama di dalam penjara menjadi semakin banyak hal yang tidak bisa di dapatkan sebelumnya ketika dia bebas di luar dan menjalankan kehidupan sebagai anggota masyarakat seperti pada umumnya.

Pelaksanaan pemberian hak yang ada dan melekat pada seseorang di seluruh dunia memang harus diberikan dari mulai hak dasar hingga hak-hak lain yang seharusnya iya dapatkan walaupun iya di dalam penjaratetapi demikian dengan dilaksanakannya kurungan bagi para pelanggar hukum membuat hak tersebut sedikit terganggu dikarenakan dia tidak mempunyai kebebasan dalam melaksanakan aktifitas tak terkecuali dengan hak biologis bagi narapidana. Namun demikian dengan adanya permasalahan ini, jajaran pemasyarakatan terus berbenah diri dalam melaksanakan kegiatan perawatan, pembinaan dan pelayanan bagi seluruh narapidana dan tahanan yang ada di dalam Lapas dengan memperhatikan pemberian hak-hak bagi narapidana walaupun ia di dalam penjara.

Namun, pemenuhan hak biologis bagi narapidana dirasa belum sesuai karena dalam pemenuhannya harus memperhatikan berbagai macam faktor. Mulai dari sarana dan prasaana, kondisi lingkungan lapas, dan kondisi sosial para narapidana. Terutama dalam upaya diciptakannya bilik asmara. Kemudian pemberian CMK juga dirasa belum sepenuhnya adil, tertutama terhadap narapidana yang dijathi hukuman seumur hidup. Seharusnya pemberian CMK harus diratakan, paling tidak bagi narapidana yang menjalani hukuman seumur hidup juga mendapatkan kesempatan untuk memenuhi kebutuhan biologisnya 
melalui CMK walaupun intensitasnya tidak sebanyak narapidana tindak pidana umum.

Pelaksanaan hak pemberian kebutuhan biologis memang sedikit terganggu tetapi tetap diusahakan dengan adanya beberapa kebijakan seperti pemberian CMK an juga adanya diciptakan bilik asmara yang dapat digunakan oleh narapidana dalam pemenuhan kebutuhan biologis mereka. Namun disamping itu narapidana tetaplah narapidana yang merupakan seorang pelanggar hukum dan pada pelaksanaannya harus diperhatikan seluruh unsurnya agar tidak terjadi masalah yang lain dan membuat permasalahan yang ada semakin rumit.

Jadi pada dasarnya kebutuhan biologis yang ada sebagai hak bagi narapidana yang ada di dalam lapas sudah diusahakan dan diberikan tetapi tetap dalam pengawasan dan apabila ada kekurangan dan kesalahan baik terhadap aturan dan norma maupun terhadap unsur lainnya maka akan dilaksanakan perbaikan sesuai dengan peraturan kebijakan yang sudah ditetapkan.

\section{E. UCAPAN TERIMA KASIH}

Pada penulisan yang dilakukan, peneliti mengucapkan terimakasih kepada seluruh unsur yang sudah memberikan kesempatan pada saya dalam menggali informasi untuk tujuan pelaksanaan pembuatan jurnal ini. Kepada bapak Kalapas Kelas II B Cianjur beserta jajaran yang telah memberikan kesempatan kepada saya untuk melaksanakan pencarian data kepada salah satu narapidana dengan vonis seumur hidup. Terimakasih saya ucapkan kepada dosen yang sudah membantu dalam penyusunan laporan ini. Semoga apa yang saya tulis dapat membantu bagi para pembaca mengenai fenomena yang terjadi dalam hal kaitannya dengan hak biologis narapidana seumur hidup yang ada di lapas kelas II B Cianjur. 


\section{F. DAFTAR PUSTAKA}

Citrawan, H. (2013). Seksualitas dalam Penjara Studi Tentang Kebutuhan Biologis Narapidana dari Perspektif Hak Asasi Manusia. Widyariset, 16(1), 31-38.

Haryono. (2017). Kebijakan Perlakuan Khusus Terhadap Narapidana Risiko Tinggi di Lembaga Pemasyarakatan (Studi Kasus di Lembaga Pemasyarakatan Kls III Gn . Sindur ). Jurnal Ilmiah Kebijakan Hukum, 11(3), 231-247.

Lubis, S. M., \& Maslihah, S. (2012). Analisis Sumber-Sumber Kebermaknaan Hidup Narapidana yang Menjalani Hukuman Seumur Hidup. Jurnal Psikologi Undip, 11(1), 28-39.

Maulani, D. G. (2014). Pidana Seumur Hidup Dalam Sistem Pemasyarakatan. FIAT JUSTISIA:Jurnal Ilmu Hukum, 6(2), 1-12. https://doi.org/10.25041/fiatjustisia.v6no2.81

Mulyana, A., Ravena, D., \& Firman, C. A. (2021). Formulation Policy Meeting the Biological Needs of Narratives in Justice Perspective. International Journal of Research and Review, 8(1), 208-218.

Rachmayanthy, Anwar, U., \& Zulfikri. (2020). Pembinaan Narapidana Teroris Di Lembaga Pemasyarakatan Super Maximum Security (SMS) Dalam Perspektif Pemasyarakatan. Jurnal of Correctional Issues (JCI), 2(1), 65-81.

Utami, P. N. (2017). Keadilan Bagi Narapidana Di Lembaga Pemasyarakatan (Justice for Convicts at the Correctionl Institutions). Jurnal Penelitian Hukum De Jure, 17(3), 381-394. 